\title{
PENERAPAN MODEL PEMBELAJARAN BERBASIS MASALAH UNTUK MENINGKATKAN HASIL BELAJAR IPA
}

\author{
Puspira Dwi Ockta $^{1 *}$, Yennita ${ }^{1}$, Irwandi Ansori ${ }^{1}$ \\ ${ }^{1}$ Program Studi Pendidikan Biologi, Fakultas Keguruan dan Ilmu Pendidikan, Universitas Bengkulu \\ Email: PuspiraDwiOcta@gmail.com
}

\begin{abstract}
Abstrak
Penelitian ini bertujuan untuk mendeskripsikan aktivitas guru dan siswa dalam pembelajaran, serta mendeskripsikan hasil belajar IPA Biologi siswa kelas VIIb SMPN 3 Marga Sakti Seblat dengan penerapan model Pembelajaran Berbasis Masalah (PBM). Penelitian ini merupakan penelitian tindakan kelas (PTK) yang dilakukan dalam dua siklus. Setiap siklus terdiri atas tahap perencanaan, pelaksanaan, tindakan dan refleksi. Subjek penelitian ini adalah guru IPA Biologi sebagai peneliti dan seluruh siswa di kelas VIIb SMPN 3 Marga Sakti Seblat. Instrumen penelitian berupa lembar observasi untuk memperoleh data aktivitas guru dan siswa serta lembar tes untuk memperoleh data hasil belajar siswa. Hasil analisis data observasi aktivitas guru pada siklus 1 diperoleh rerata skor 21 dengan kriteria baik, kemudian meningkat disiklus II skor aktivitas guru meningkat menjadi 22 dengan kriteria baik. Hasil analisis data observasi aktivitas siswa pada siklus 1 diperoleh rerata skor 21 dengan kriteria baik, kemudian meningkat disiklus II menjadi 22 dengan kriteria baik. Presentase ketuntasan belajar klasikal pada siklus I sebesar 47,22 \% dengan kriteria belum tuntas, kemudian meningkat pada siklus II menjadi $75 \%$ dengan kriteria tuntas. Dari hasil analisa data tersebut dapat disimpulkan bahwa dengan penerapan model PBM dapat meningkatkan aktivitas guru dan siswa serta hasil belajar IPA Biologi siswa kelas VIIb SMPN 3 Marga Sakti Seblat.
\end{abstract}

Kata kunci: Hasil Belajar, Aktivitas belajar dan mengajar, Pembelajaran Berbasis Masalah

\begin{abstract}
Abstrack
This study aimed to describe activities of teachers and students in learning, and student learning outcomes for IPA Biologi in class VIIb SMPN 3 Marga Sakti Seblat by application of Problem Based Learning design (PBL) model. This type of research was classroom action research with descriptive method. This research was conducted for two cycles, which each cycle consisting of planning, implementation, observation, and reflection. The subject of this research was the researcher who acted as the teacher and all the students of class VIIb SMPN 3 Marga Sakti Seblat. The research instrument was observation sheet to determined activity of teacher and students, and test sheet to determined student learning ooutcomes. Observation data of teacher activity in first cycle resulted scores average 21 (Good) and in second cycle II scores was increased to 22 (Good). The results of data analysis of student activity observation was also increased, which in first cycle resulted scores average 21 (Good), while in second cycle was increased to 22 (Good). Percentage of classical learning completeness by students in first cycle was $47,22 \%$ (Uncompleted) and was increased to $75 \%$ (completed) in second cycle. From the data analysis can be concluded that the application of problem based learning model can improved the activities of teacher and student learning, and students learning outcomes IPA Biologi in class VIIb SMPN 3 Marga Sakti Seblat.
\end{abstract}

Keywords : Learning Outcomes, Teacher and student Activity, Problem Based Learning model 


\section{PENDAHULUAN}

Pendidikan merupakan faktor utama dalam pembentukkan pribadi manusia serta penting untuk mengembangkan dan memajukan kehidupan suatu negara. Pendidikan dapat diartikan sebagai suatu proses dengan metode-metode tertentu sehingga seseorang dapat memperoleh pengetahuan, pemahaman, dan cara bertingkah laku yang sesuai dengan kebutuhan (Suryadi, 2014). Hal ini selaras dengan tujuan pendidikan nasional pada UU RI, No. 20 tahun 2003 yang menyatakan : mengembangkan kemampuan dan membentuk watak peradaban bangsa yang bermartabat dalam rangka mencerdaskan kehidupan bangsa bertujuan untuk berkembangnya potensi peserta didik agar menjadi manusia beriman dan bertaqwa kepada TME, berakhlak mulia, sehat, berilmu, cakap, kreatif, mandiri, dan menjadi warga negara yang demokratis serta tanggung jawab.

Berdasarkan observasi awal dan wawancara dengan guru IPA biologi kelas VIIb SMPN 3 Marga Sakti Seblat Bengkulu Utara tahun ajaran 2016/2017 yang dilakukan peneliti pada bulan Januari 2017 di perolah data presentase ketuntasan belajar siswa mencapai $35 \%$ dari 36 orang siswa, sedangkan angka ketuntasan belajar siswa yang diharapkan yaitu $75 \%$.

Rendahnya persentase ketuntasan belajar siswa tersebut antara lain disebabkan guru kurang melibatkan siswa dalam memecahkan masalah-masalah yang timbul dikehidupan nyata dan guru tidak mengkaitkan masalah-masalah tersebut dengan materi pembelajaran biologi. Selain itu siswa masih menjadikan guru sebagai satu-satunya sumber belajar, meskipun guru telah memberikan kesempatan siswa untuk mencari informasi dari sumber lainnya.

Berdasarkan permasalahan tersebut maka peneliti berkolaborasi dengan guru IPA Biologi melakukan penelitian yang bertujuan untuk memperbaiki hasil belajar siswa di kelas
VIIb SMPN 3 Marga Sakti Seblat dengan menerapkan model Pembelajaran Berbasis Masalah (PBM). PBM dipilih karena model ini proses menalarnya nyata atau konkret sehingga dapat diterapkan secara komperhensif. Dalam PBM terdapat unsur menemukan masalah (problem possing) dan sekaliagus memecahkan masalah (problem solving). Selain itu model PBM belum pernah diterapkan oleh guru SMPN 3 Marga Sakti Seblat pada pembelajaran biologi, sehingga diharapkan dapat lebih baik dari model pembelajaran sebelumnya karena memfokuskan siswa agar dapat memecahkan masalah dengan cara mereka sendiri.

Menurut Tan dalam Rusman (2014), pembelajaran berbasis masalah merupakan inovasi dalam pembelajaran karena dalam PBM kemampuan berpikir siswa betul-betul dioptimalisasikan melalui proses kerja kelompok atau tim yang sistematis, sehingga siswa dapat memperdayakan, mengasah, menguji, dan mengembangkan kemampuan berpikirnya secara berkesinambungan. Pada kenyataannya, tidak semua guru memahami konsep PBM, baik disebabkan oleh kurangnya keinginan dan motivasi untuk meningkatkan kualitas keilmuan maupun karena kurangnya dukungan sistem untuk meningkatkan kualitas keilmuan tenaga pendidik.

Model PBM sesuai digunakan untuk mengajar materi Interaksi Makhluk Hidup dengan Lingkungan. Walaupun materi ini termasuk ke dalam materi yang tidak terlalu sulit, namun kebanyakan dari siswa tidak berfikir secara kritis dan semua proses pembelajaran hanya berpusat pada guru. Padahal materi ini sangat berkaitan erat dengan kehidupan sehari-hari siswa.

Rumusan masalah dalam penelitian ini adalah : 1) Bagaimana aktivitas mengajar guru dan aktivitas belajar siswa kelas VIlb SMPN 3 Marga Sakti Seblat pada materi Interaksi Makhluk Hidup dengan Lingkungan menggunakan model PBM?, 2) Bagaimana hasil belajar siswa Kelas VIIb SMPN 3 Marga Sakti Seblat pada materi Interaksi Makhluk Hidup 
dengan Lingkungan dengan penerapan model PBM ?

Tujuan penelitian ini adalah :

1) Mendeskripsikan aktivitas mengajar guru dan belajar siswa kelas VIIb SMPN 3 Marga Sakti Seblat menggunakan model PBM pada materi Interaksi Makhluk Hidup dengan Lingkungan, 2) Mendeskripsikan peningkatan hasil belajar siswa kelas VIIb SMPN 3 Marga Sakti Seblat menggunakan model PBM pada materi Interaksi Makhluk Hidup dengan Lingkungan.

\section{METODE}

Penelitian ini merupakan Penelitian Tindakan Kelas, dengan metode penelitian deskriptif. Menurut Zuriah (2009), penelitian deskriptif dapat diartikan sebagai penelitian yang diarahkan untuk memberikan gejalagejala, fakta-fakta, atau kejadian-kejadian, secara sistematis dan akurat, mengenai sifatsifat populasi atau daerah tertentu, dengan tujuan menggambarkan secara sistematis fakta dan karakteristik objek yang di teliti secara tepat.

Subyek penelitian ini adalah peneliti yang bertindak sebagai guru IPA Biologi dan siswa kelas VIIb SMPN 3 Marga Sakti Seblat tahun ajaran 2017/2018, yang berjumlah 36 orang siswa, terdiri dari 18 siswa perempuan dan 18 siswa laki-laki. Pemilihan kelas VII berdasarkan pada pertimbangan bahwa di kelas VII pembelajaran siswa masih tergolong pasif dan hanya kelas VII di SMPN 3 Marga Sakti Seblat yang sudah menggunakan kurikulum 2013.

Teknik pengumpulan data dalam penelitian ini adalah observasi dan tes. Observasi dilakukan untuk mengetahui aktivitas guru dan aktivitas siswa selama proses pembelajaran IPA Biologi di kelas VIIb SMPN 3 Marga Sakti Seblat. Sedangkan tes digunakan untuk mengumpulkan data hasil belajar siswa secara individu setelah proses belajar dengan menerapkan model Pembelajaran Berbasis Masalah (PBM), yang mengacu pada kompetensi dasar (KD) 3.8 yaitu mendeskripsikan interaksi antar mahluk hidup dan lingkungannya, dan 4.12 yaitu menyajikan hasil observasi terhadap interaksi mahluk hidup dengan lingkungan sekitarnya.

Data hasil observasi terhadap aktivitas guru dan siswa dalam proses pembelajaran IPA ini dianalisis dengan menghitung rata-rata skor pengamat sehingga dapat diungkapkan secara deskriptif. Perhitungan dilakukan dengan menggunakan rumus :

Rata-rata skor $=\frac{\text { Jumlah } \text { skor }}{\text { Jumlah } \text { observer }}$

1) Skor tertinggi = Jumlah aspek yang diamati $\times$ skor tertinggi setiap aspek

2) Skor terendah = jumlah aspek yang diamati $\times$ skor terendah setiap aspek

3) Selisih skor = Skor tertinggi - Skor terendah

4) Kisaran nilai untuk tiap kriteria pengamatan $=\frac{\text { Selisih skor }}{\text { Jumlah kriteria penilaian }}$

(Arikunto, 2010).

Data hasil belajar siswa dianalisis dengan cara mengolah data hasil post tes sehingga dapat diketahui tingkat keberhasilan atau ketuntasan siswa di kelas VIIb SMPN 3 Marga Sakti Seblat. Untuk menganalisis ketercapaian hasil belajar siswa maka dihitung persentase kriteria ketuntasan belajar siswa (Arikunto, 2010), dengan rumus :

$$
K B=\frac{N S}{N} \times 100 \%
$$

Keterangan:

$\mathrm{KB}=$ Ketuntasan belajar klasikal

$\mathrm{NS}=$ jumlah siswa yang mendapat nilai $\geq 70 \mathrm{~N}$ = jumlah siswa

\section{HASIL DAN PEMBAHASAN}

Berdasarkan penelitian yang telah dilaksanakan di kelas $\mathrm{VII}_{\mathrm{b}}$ SMPN 3 Marga Sakti Seblat dengan menerapkan Model Pembelajaran Berbasis Masalah (PBM), sebanyak 2 siklus berfokus pada aktivitas mengajar guru, aktivitas belajar siswa dan hasil belajar siswa pada materi Interaksi Makhluk Hidup Dengan Lingkungan, diperoleh hasil : 


\section{Deskripsi Hasil Observasi Aktivitas Guru pada Siklus I dan II}

Observasi aktivitas guru digunakan sebagai acuan observer untuk mengetahui kelebihan dan kekurangan yang dilakukan guru pada saat proses pembelajaran berlangsung dan sebagai pedoman untuk memperbaiki pelaksanaan proses belajar mengajar pada siklus selanjutnya. Adapun hasil observasi aktivitas guru secara terperinci dari masing-masing siklus dapat dilihat pada Tabel 1 dan Tabel 2.

Tabel 1. Data Hasil Observasi Terhadap Aktivitas Guru pada Siklus I

\begin{tabular}{ccc}
\hline No & Pengamat & Skor \\
\hline 1 & $\mathrm{I}$ & 21 \\
2 & $\mathrm{II}$ & 21 \\
Total Skor & & 42 \\
Rerata Skor & & 21 \\
Kriteria & & Baik \\
\hline
\end{tabular}

Tabel 2. Data Hasil Observasi Terhadap Aktivitas Guru pada Siklus II

\begin{tabular}{lcc}
\hline No & Pengamat & Skor \\
\hline 1 & $\mathrm{I}$ & 22 \\
2 & $\mathrm{II}$ & 22 \\
Total Skor & & 44 \\
Rerata Skor & 22 \\
Kriteria & & Baik \\
\hline
\end{tabular}

\section{Deskripsi Hasil Observasi Aktivitas Siswa} Siklus I dan II

Observasi aktivitas siswa digunakan sebagai acuan observer untuk mengetahui keaktifan dan keikutsertaan siswa dalam mengikuti proses belajar pada setiap tahaptahap pembelajaran. Adapun hasil observasi aktivitas siswa secara terperinci dari masingmasing siklus dapat dilihat pada Tabel 3 dan Tabel 4.

Tabel 3. Data Hasil Observasi Terhadap Aktivitas Siswa pada Siklus I

\begin{tabular}{lcr}
\hline No & Pengamat & Skor \\
\hline 1 & $\mathrm{I}$ & 21 \\
2 & $\mathrm{II}$ & 21 \\
Total Skor & & 42 \\
Rerata Skor & 21 \\
\hline
\end{tabular}

\begin{tabular}{ll}
\hline Kriteria & Baik \\
\hline
\end{tabular}

Tabel 4. Data Hasil Observasi Terhadap Aktivitas Siswa pada Siklus II

\begin{tabular}{lcc}
\hline No & Pengamat & Skor \\
\hline 1 & $\mathrm{I}$ & 22 \\
2 & $\mathrm{II}$ & 22 \\
Total Skor & & 44 \\
Rerata Skor & 22 \\
Kriteria & Baik \\
\hline
\end{tabular}

\section{Deskripsi Hasil Belajar Siswa Siklus I dan II}

Nilai akhir pembelajaran biologi pada materi Interaksi Makhluk Hidup dengan Lingkungan menggunakan model Pembelajaran Berbasis Masalah (PBM) diperoleh dengan penilaian berupa tes tertulis. Soal-soal tes dibuat dalam bentuk essai dengan jumlah 5 soal. Dari nilai tersebut dihitung dengan menggunakan rumus persentase ketuntasan belajar siswa dengan menggunakan persentase ketuntasan belajar klasikal dapat dilihat pada Tabel 5.

Tabel 5 Data Hasil Belajar Siswa pada Siklus I dan Siklus II

\begin{tabular}{|l|c|c|c|c|c|c|}
\hline Siklus & $\mathbf{N}$ & $\mathbf{\Sigma X}$ & $\mathbf{X}$ & $\begin{array}{c}\text { nilai } \\
\mathbf{2 7 0}\end{array}$ & $\mathbf{K B}(\%)$ & $\begin{array}{c}\text { Kriteri } \\
\mathbf{a}\end{array}$ \\
\hline I & 36 & 2253 & $\begin{array}{l}62,5 \\
8\end{array}$ & 17 & 47,22 & $\begin{array}{c}\text { Belum } \\
\text { tuntas }\end{array}$ \\
\hline II & 36 & 2772 & 77 & 27 & $75 \%$ & Tuntas \\
\hline
\end{tabular}

\section{Keterangan :}

$\mathrm{N}$ : Jumlah seluruh siswa

$X$ : Nilai rata-rata kelas

$\Sigma X$ : Jumlah nilai keseluruhan siswa

KB : Persentase ketuntasan belajar

Hasil penelitian menunjukkan bahwa penerapan model PBM pada pokok bahasan Interaksi Makhluk Hidup dengan Lingkungan 
dapat meningkatkan aktivitas guru dan aktivitas siswa, serta hasil belajar siswa selama kelas VIIb SMPN 3 Marga Sakti Seblat. Pada siklus I skor yang diberikan observer untuk aktivitas guru adalah 42 dengan kriteria baik, kemudian pada siklus II terjadi peningkatan skor menjadi 44 dengan kriteria baik. Hal ini juga didukung dengan aktivitas belajar siswa yang diamati oleh observer, dimana pada siklus I aktivitas siswa menunjukan kategori baik dengan skor 42, dan meningkat pada siklus II menjadi 44.

Persentase ketuntasan hasil belajar siswa pada siklus I adalah 47,22\%, dan meningkat pada siklus II menjadi $75 \%$. Pada siklus I disampaikan sub materi Komponen Penyusun Ekosistem, selanjutnya pada siklus II disampaikan sub materi Interaksi Makhluk Hidup Membentuk Suatu Pola. Model pembelajaran berbasis masalah dilakukan melalui lima tahapan, yang dapat dideskripsikan sebagai berikut.

\section{a. Aktivitas Guru}

\section{1). Orientasi siswa kepada masalah}

Pada tahap ini kegiatan guru yang dilakukan meliputi: menyampaikan tujuan pembelajaran, mengajukan fenomena dalam kehidupan untuk memunculkan masalah, dan memotivasi siswa untuk terlibat dalam pemecahan masalah. Pada siklus I dan siklus II guru menjelaskan tujuan pembelajaran dan siswa diminta untuk mencatat tujuan pembelajaran tersebut. Lalu siswa dilibatkan dalam cerita untuk memunculkan apersepsi yang bertujuan menggali pengetahuan awal siswa. Kemudian guru mengajukan fenomena dalam kehidupan untuk memunculkan masalah, dan memotivasi siswa untuk terlibat dalam pemecahan masalah tersebut.

Masalah yang disampaikan pada saat pembelajaran berupa artikel yang berjudul “ Hamparan Pertambangan Batu Bara Sikat Habis Lahan Perkebunan". Guru membahas mengenai masalah tersebut, dengan pokok pembahasan bahwa komponen abiotik dan biotik yang awalnya seimbang berubah menjadi masalah karena seluruh lahan perkebunan dialihkan menjadi lahan pertambangan batu bara yang seluruhnya komponen abiotik. Setelah itu guru mengkaitkan masalah dengan lingkungan sekolah, dan menanyakan "Apakah komponen lingkungan sekolah kalian seimbang? Nanti kita akan buktikan dengan pengamatan langsung ke lapangan".

Pada siklus II guru menyampaikan fenomena dalam kehidupan berupa masalah dengan menggunakan artikel yang berjudul "Macan Tutul Masuk ke Pemukiman Warga di Dayeuhluhur", dan meminta seluruh siswa membaca. Namun pemunculan masalah pada silklus II ini kurang efektif, karena hanya mencakup pada satu sub materi saja dan penyampaiannya berbelit-belit. Walaupun demikian seluruh permasalahan yang dimunculkan sesuai dengan materi yang diajarkan dan tujuan pembelajaran pada hari itu.

Mengajukan fenomena dalam kehidupan untuk memunculkan masalah, dan memotivasi siswa untuk terlibat dalam pemecahan masalah adalah konsep belajar menggunakan metode Pembelajaran Berbasis Masalah (PBM). Hal ini sesuai dengan pernyataan Rusman (2014) bahwa guru berperan menghantarkan siswa memahami konsep dan menyiapkan situasi dengan pokok bahasan yang diajarkan. Selanjutnya siswa mengkonstruksi sebanyak mungkin masalah untuk meningkatkan pengembangan pemahaman konsep, aturan, dan teori dalam pemecahan masalah.

\section{2). Mengorganisasikan siswa untuk belajar}

Pada tahapan ini guru membimbing siswa dalam pembagian kelompok. Pada siklus I, tahapan ini memakan waktu yang cukup banyak. Sebelumnya guru (peneliti) telah menanyakan kepada guru IPA SMPN 3 Marga Sakti Seblat mengenai kelompok belajar siswa dan dikatakan bahwa untuk mata pelajaran IPA siswa sudah memiliki kelompok belajar. Namun saat proses pembelajaran berlangsung, ketika siswa diminta untuk duduk berkelompok beberapa orang siswa lupa dengan kelompoknya, dengan alasan kelompok tersebut sudah lama dibentuk dan proses pembelajaran jarang berkelompok. Hal inilah yang membuat banyak waktu terbuang. Pada 
siklus II pembagian kelompok berjalan dengan baik. Guru hanya memberikan intruksi dan membimbing siswa untuk membentuk kelompok. Setelah kelompok terbentuk lalu guru membagikan bahan ajar berupa LKS (pengamatan lingkungan sekolah) pada siklus I dan LDS (diskusi materi antar kelompok) pada siklus II.

Pembentukan kelompok dalam pembelajaran ini bertujuan untuk mendorong siswa berkolaborasi dan dapat bekerja sama dengan tim. Hal ini sesuai dengan pernyataan Kosasih (2014) bahwa PBM juga mendorong siswa untuk terbiasa berkolaborasi dengan temannya. Hal ini dikarenakan dalam pelaksanaan model PBM tersebut tidak terlepas dari kegiatan sumbang saran antar siswa yang satu dengan yang lainnya, termasuk dalam rangkaian kegiatan usaha dalam menemukan solusinya.

\section{3). Membimbing penyelidikan individual maupun kelompok}

Pada tahap orientasi siswa kepada masalah ada beberapa kegiatan guru yang meliputi: mendorong siswa secara kelompok mengumpulkan informasi yang sesuai, melaksanakan pengamatan dan diskusi untuk mendapatkan hasil dari pemecahan masalah pada materi Interaksi Makhluk Hidup dengan Lingkungan, dan membimbing siswa secara individual untuk aktif ikut memecahkan masalah yang telah disajikan.

Pada siklus I, tahapan guru mendorong siswa secara kelompok mengumpulkan informasi yang sesuai, melaksanakan diskusi untuk mendapatkan hasil dari pemecahan masalah pada materi Interaksi Makhluk Hidup dengan Lingkungan sudah dilakukan dengan baik. Namun masih terdapat kekurangan pada saat pelaksanaan penelitian di lingkungan sekolah karena areanya yang terlalu luas dan beberapa kelompok terpencar, sehingga menyebabkan guru kurang efektif dalam membimbing pengamatan siswa. Akibatnya hanya empat kelompok yang benar-benar terbimbing. Pada siklus II, tahapan ini berjalan sesuai harapan, dikarenakan siswa melakukan diskusi di dalam kelas dan situasi kelas kondusif.

Pada siklus I dan II , tahapan membimbing siswa secara individual untuk aktif ikut memecahkan masalah yang telah disajikan sudah berkriteria baik. Pada tahap ini guru membimbing siswa secara berkelompok untuk berdiskusi dan aktif secara individual. Hal ini di dukung pernyataan Putra (2013) bahwa PBM bertujuan mengembangkan dan menerapkan kecakapan yang penting, yakni pemecahan masalah, belajar sendiri, kerja sama tim, dan memperoleh pengetahuan yang luas.

\section{4.) Mengembangkan dan menyajikan hasil karya}

Pada tahap ini guru membantu siswa dalam merencanakan dan menyiapkan hasil karya yang berupa laporan kelompok serta membantu mereka untuk berbagi tugas dengan temannya. Pada siklus I dan siklus II setelah melakukan pengamatan dan diskusi, siswa diminta untuk membuat suatu karya berupa laporan dengan cara bekerja sama antar anggota kelompok. Setelah itu guru meminta salah satu kelompok yang diwakili oleh satu anggota kelompok untuk mempresentasikannya ke depan kelas. Setiap satu poin bahasan guru langsung menanyakan kepada kelompok lain "Bagaimana, apakah semua sama atau ada yang beda ? Jika berbeda di bagian mana dan tolong jelaskan pendapat menurut kelompok kalian", kemudian kelompok lain menanggapi. Kegiatan tersebut terus berulang hingga pada poin kesimpulan.

Mengkomunikasikan atau mempresentasikan hasil karya seperti ini sangat diperlukan karena dapat melatih siswa berkomunikasi dengan pihak lain. Hal ini sesuai dengan pernyataan Putra (2013) bahwa melalui pendekatan PBM siswa mempresentasikan gagasannya, siswa terlatih merefleksikan persepsinya, mengargumentasikan dan mengomunikasikan ke pihak lain sehingga guru pun memahami proses berpikir siswa, dan guru dapat membimbing serta mengintervensikan ide baru berupa konsep dan prinsip. 


\section{5). Menganalisis dan mengevaluasi proses pemecahan masalah}

Pada tahap ini kegiatan guru ialah membantu siswa untuk melakukan refleksi atau evaluasi terhadap penyelidikan yang mereka lakukan pada materi Interaksi Makhluk Hidup Dengan Lingkungan.

Pada siklus I proses refleksi atau evaluasi yang dilakukan oleh guru tidak berlangsung lama dikarenakan waktu yang digunakan untuk berdiskusi terlalu lama, menyebabkan pengulasan materi, dan pemberian jawaban yang benar dari diskusi yang seharusnya di sampaikan dengan baik oleh guru tidak bisa dilakukan dengan masksimal karena kurangnya waktu. Pada refleksi observer memberi saran agar guru dapat membagi waktu pada saat proses mengajar.

Pada siklus II guru memperbaiki kekurangan di siklus I yaitu proses refleksi. Pada tahap ini siswa melakukan refleksi terhadap proses pembelajaran yang telah berlangsung tetapi masih belum maksimal. Seperti juga siklus sebelumnya, pengulasan materi dan jawaban yang benar hanya dibahas sedikit kemudian guru sedikit memberikan penguatan kepada siswa. Diakhir pembelajaran guru meminta siswa untuk menyimpulkan pembelajaran yang telah dilakukan. Hal ini sesuai dengan pernyataan Rusman (2014) yang menyatakan bahwa peran siswa secara khusus adalah berpartisipasi dalam pengembangan serta penggunaan assesment untuk mengevaluasi kemajuan diri sendiri.

\section{b. Aktivitas Siswa}

\section{1). Orientasi siswa kepada masalah}

Tahapan orientasi siswa pada masalah meliputi beberapa kegiatan siswa yaitu : memperhatikan dan mencatat tujuan pembelajaran, terlibat dalam cerita untuk memunculkan masalah, dan termotivasi untuk terlibat dalam pemecahan masalah.

Pada siklus I dan siklus II seluruh siswa sudah mencatat tujuan pembelajaran yang telah dijelaskan oleh guru. Siswa ikut terlibat dalam cerita untuk memunculkan masalah dan siswa termotivasi untuk terlibat dalam pemecahan masalah yang ada. Hal ini sesuai dengan pernyataan Khalifah (2013) bahwa tujuan pembelajaran merupakan harapan siswa terhadap hasil pembelajaran, sehingga dalam proses pembelajaran guru harus menjelaskan dan menuliskan tujuan pembelajaran di papan tulis supaya siswa dan guru melaksanakan proses pembelajaran sesuai dengan tujuan dan supaya siswa dan guru mengetahui apa yang akan dicapai pada proses pembelajaran.

\section{2). Mengorganisasikan siswa untuk belajar}

Pada tahap orientasi siswa untuk belajar, kegiatan siswa hanya duduk berkelompok sesuai kelompok belajar. Pada siklus I pembagian kelompok tidak berlangsung dengan lancar karena saat guru meminta siswa untuk duduk sesuai dengan kelompok yang telah dibentuk oleh guru IPA SMPN 3 Marga Sakti Seblat, beberapa orang siswa lupa dengan kelompoknya, dengan alasan kelompok tersebut sudah lama dibentuk dan proses pembelajaran jarang berkelompok. Hal ini menyebabkan banyak waktu yang terbuang.

Pada siklus II tahapan ini berjalan dengan baik, seluruh siswa bergegas duduk sesuai kelompoknya masing-masing saat guru memberikan intruksi untuk duduk berkelompok.

Pembentukan kelompok ini bertujuan untuk mendorong siswa berkolaborasi dan dapat bekerja sama dengan tim. Hal ini sesuai dengan pernyataan Kosasih (2014) bahwa PBM juga mendorong siswa untuk terbiasa berkolaborasi dengan temannya. Hal ini karena dalam pelaksanaan model PBM tersebut mereka tidak terlepas dari kegiatan sumbang saran antar siswa yang satu dengan yang lainnya, termasuk dalam rangkaian kegiatan usaha dalam menemukan solusinya.

\section{3). Membimbing penyelidikan individual maupun kelompok}

Pada tahap orientasi siswa pada masalah ada beberapa kegiatan siswa yaitu : Siswa secara kelompok mengumpulkan informasi 
yang sesuai, melaksanakan diskusi untuk mendapatkan penjelasan dan pemecahan masalah pada materi Interaksi Makhluk Hidup dengan Lingkungan, dan siswa secara individual aktif untuk ikut memecahkan masalah yang telah disajikan.

Pada siklus I dan siklus II siswa secara berkelompok mampu mengumpulkan informasi yang sesuai dan melaksanakan diskusi materi Interaksi Makhluk Hidup Dengan Lingkungan. Namun pada saat memecahkan masalah, dua kelompok dan beberapa orang siswa masih kurang aktif.

Setelah melakukan refleksi pada siklus I, masih ada beberapa siswa yang kurang aktif dalam memecahkan masalah. Hal ini disebabkan pada siklus I saat pengamatan lapangan, area yang dipilih terlalu luas sehingga beberapa kelompok menyebar, menyebabkan guru tidak dapat membimbing seluruh kelompok. Berbeda dengan siklus II, pemecahan masalah dilakukan di dalam kelas. Namun masih ada dua kelompok siswa yang tidak aktif dalam pemecahan masalah. Hal ini disebabkan volume suara guru kurang keras yang memungkinkan siswa menjadi jenuh dan kurang tertarik dalam memecahkan masalah.

\section{4). Mengembangkan dan menyajikan hasil karya}

Pada tahapan ini aktivitas siswa yaitu merencanakan dan menyiapkan hasil karya yang berupa laporan kelompok serta membantu mereka untuk berbagi tugas dengan temannya.

Pada siklus I seluruh siswa yang telah melakukan pengamatan dan diskusi lalu membuat atau menyiapkan suatu karya berupa laporan yang di tugaskan oleh guru. Namun masih ada siswa yang tidak ikut terlibat dalam pembuatan laporan ini dan hanya mengandalkan teman kelompoknya. Saat guru mendekat dan menegur barulah siswa-siswa tersebut ikut membantu. Setelah itu perwakilan dari satu kelompok maju untuk mempresentasikan laporan tersebut. Seluruh poin bahasan didiskusikan antar tiap kelompok dengan bantuan guru sebagai moderator.
Seluruh kelompok tampak aktif saat membandingkan jawaban mereka dengan kelompok lain, namun masih saja beberapa anggota kelompok tidak bersemangat saat berdiskusi.

Setelah melakukan refleksi pada siklus I, siswa memperbaiki dan membagi waktu sebaik mungkin untuk melakukan tahapn ini secara maksimal dengan lebih serius dalam mempresentasikan hasil karyanya. Pada siklus II masih ada anggota kelompok yang tidak ikut bekerjasama dalam pembuatan laporan.

Mengkomunikasikan atau mempresentasikan hasil karya seperti ini sangat diperlukan karena dapat melatih siswa berkomunikasi dengan pihak lain. Hal ini sesuai dengan pernyataan Putra (2013) bahwa melalui pendekatan PBM siswa mempresentasikan gagasannya, terlatih merefleksikan persepsinya, mengargumentasikan dan mengomunikasikan ke pihak lain sehingga guru memahami proses berpikir siswa dan dapat membimbing serta mengintervensikan ide baru berupa konsep dan prinsip. Dengan demikian, pembelajaran berlangsung sesuai dengan kemampuan siswa, sehingga interaksi antara guru dan siswa, serta siswa dengan siswa menjadi terkondisi dan terkendali.

\section{5). Menganalisis dan mengevaluasi proses pemecahan masalah}

Pada tahapan ini kegiatan siswa meliputi : melakukan refleksi atau evaluasi. Pada siklus I dan siklus II proses refleksi yang dilakukan siswa berlangsung baik, siswa mendengarkan dan memperhatikan pengulasan materi oleh guru, proses tanya jawab dan mencatat jawaban yang benar dari diskusi yang telah dilakukan. Diakhir pembelajaran siswa menyimpulkan pembelajaran yang telah dilakukan. Guru memberikan evaluasi berupa tes tertulis dalam bentuk esai dengan jumlah 5 soal yang dilaksanakan pada akhir pembelajaran.

Hal ini sesuai dengan pernyataan Rusman (2014) yang menyatakan bahwa peran siswa secara khusus adalah berpartisipasi dalam pengembangan serta penggunaan 
assesment untuk mengevaluasi kemajuan diri sendiri. Pembelajaran Berbasis Masalah melibatkan siswa dan penyelidikan yang memungkinkan mereka menginterpretasikan dan menjelaskan dunia nyata dan membangun pemahamannya tentang fenomena itu.

\section{Hasil belajar siswa Kelas $\mathrm{VII}_{\mathrm{b}}$ SMPN 3 Marga Sakti Seblat}

Model Pembelajaran Berbasis Masalah (PBM) pada pembelajaran biologi materi Interaksi Makhluk Hidup Dengan Lingkungan selain meningkatkan aktivitas guru dan aktivitas belajar siswa, juga meningkatkan hasil belajar siswa. Hal ini dapat dilihat dari nilai tes yang telah dilakukan dalam dua siklus. Menurut Hosnan (2014), hasil belajar adalah kemampuan perubahan perilaku baik peningkatan pengetahuan, perbaikan sikap, maupun peningkatan keterampilan yang dialami siswa yang diperoleh setelah melalui kegiatan pembelajaran. Hasil belajar yang dimaksud dalam penelitian ini hanyalah hasil belajar secara kognitif (kawasan kognitif) yang dicapai siswa selama proses pembelajaran berlangsung.

Untuk melihat hasil belajar siswa, guru menggunakan tes tertulis berbentuk essay yang disajikan di akhir pembelajaran (post-test). Materi yang digunakan yaitu Interaksi Makhluk Hidup dengan Lingkungan dalam bentuk esai yang terdiri dari 5 butir soal yang terdiri dari soal C1, C2, dan C3. Dilakukan dalam dua siklus.

Persentase ketuntasan hasil belajar pada siklus I adalah 47,22 \% (Tabel 4.5) yang berarti secara klasikal dinyatakan belum tuntas. Kemudian pada siklus II dilakukan refleksi terhadap siklus I, dimana kekurangan pada siklus I diperbaiki pada siklus II. Ketuntasan hasil belajar siswa pada siklus II adalah 75\% (Tabel 4.6) yang berarti pada siklus II hasil belajar secara klasikal dinyatakan tuntas.

Berdasarkan proses pembelajaran yang telah dilakukan diketahui bahwa penerapan Model Pembelajaran Berbasis Masalah pada proses pembelajaran dapat meningkatkan hasil belajar siswa dan meningkatkan aktivitas belajar siswa guna meningkatkan pola pikir siswa untuk memecahkan masalah yang dihadapi secara individu dan kelompok. Peningkatan hasil belajar klasikal siswa ini terjadi karena guru memberikan kesempatan kepada siswa aktif pada saat pembelajaran seperti mengumpulkan data, mengolah data dan memecahkan masalah untuk memperoleh hasil berupa pemahaman dalam materi yang dipelajari.

\section{PENUTUP \\ Simpulan}

Berdasarkan Penelitian Tindakan Kelas (PTK) yang dilakukan di Kelas VIIb SMPN 3 Marga Sakti Seblat dengan menggunakan model Pembelajaran Berbasis Masalah (PBM) pada materi Interaksi Makhluk Hidup Dengan Lingkungan yang dilakukan dalam dua siklus dapat disimpulkan bahwa :

1. Perbaikan pembelajaran dengan model Pembelajaran Pembelajaran Berbasis Masalah (PBM) dalam proses pembelajaran Biologi Materi Interaksi Makhluk Hidup Dengan Lingkungan dapat meningkatkan aktivitas mengajar guru dan aktivitas belajar siswa Kelas VIIb SMPN 3 Marga Sakti Seblat dengan rerata skor aktivitas mengajar dari 21 menjadi 22 dan aktivitas belajar siswa dengan rerata 21 menjadi 22 .

2. Perbaikan pembelajaran dengan model Pembelajaran Pembelajaran Berbasis Masalah (PBM) dalam proses pembelajaran Biologi pada materi Interaksi Makhluk Hidup Dengan Lingkungan dapat meningkatkan hasil belajar siswa Kelas VIIb SMPN 3 Marga Sakti Seblat yaitu dengan ketuntasan klasikal dari 47,22\% menjadi $75 \%$.

\section{Saran}

Berdasarkan hasil penelitian yang telah dilakukan, beberapa saran yang dapat dianjurkan yaitu:

1. Diharapkan kepada guru mata pelajaran biologi Kelas VII b SMPN 3 Marga Sakti Seblat akan model Pembelajaran Berbasis Masalah sebagai suatu alternatif dalam pembelajaran untuk diterapkan pada pembelajaran Biologi sebagai upaya 
meningkatkan hasil belajar siswa dengan menggunakan tahapan pembelajaran yang tepat.

2. Untuk peneliti selanjutnya diharapkan peneliti harus meranacang strategi pembelajaran dengan tepat dan harus memperhatikan tahap-tahap pada sintaks serta managemen waktu yang lebih baik agar dapat menggunakan Model Pembelajaran Berbasis Masalah (PBM) sesuai tahapan-tahapanya untuk mendapatkan hasil yang maksimal.

\section{DAFTAR PUSTAKA}

Arikunto, dkk. 2010. Prosedur penelitian Suatu Pendekatan Praktik. Jakarta : Rineka Cipta.

Khalifah, Siti. 2013. Metode Penelitian Pendidikan. Jakarta : Rineka Cipta.

Kosasih. 2014. Strategi Belajar dan Pembelajaran. Bandung : Yrama Widya

Putra, Sitiatava Rizema. 2013. Desain Belajar Mengajar Kreatif Berbasis Sains. Yogyakarta: Diva Press.

Rusman. 2014. Model-model pembelajaran mengembangkan profesionalisme guru. Jakarta: Rajawali Pers.

Suryadi, Ace. 2014. Pendidikan Indonesia Menuju 2025. Bandung : PT Remaja Rosdakarya.

Zuriah, Nurul. 2009. Metodologi Penelitian Sosial dan Pendidikan. Jakarta : PT Bumi Aksara 